\title{
Os heróis maçônicos na historiografia da aboliçāo em Sāo Paulo
}

\author{
Masonic heroes in the historiography of abolition in Sāo Paulo
}

\author{
Renata Ribeiro Francisco ${ }^{a}$ \\ E-mail: renataribeirofrancisco@gmail.com \\ http://orcid.org/0000-0002-9021-6600 iD
}

a Universidade de São Paulo, Faculdade de Filosofia, Letras e Ciências Humanas, Departamento de História, São Paulo, SP, Brasil

\section{RESUMO}

Nascida como organização de ajuda-mútua, a maçonaria ganharia novos contornos, consolidando-se como importante espaço de sociabilidade na segunda metade do século XVIII e, institucionalizada no Brasil no início do século XIX. A irmandade engrossou suas fileiras incorporando em sua organização importantes personagens de seu tempo, de políticos da alta cúpula a ativistas influentes. O presente artigo apresenta o debate historiográfico acerca da construção das memórias da Abolição da Escravatura, a partir da hipótese de que a maçonaria estrategicamente escolheu evocar a imagem de alguns personagens de sua história, a fim de cimentar positivamente suas experiências e seu suposto protagonismo através das narrativas maçônicas contemporâneas confeccionadas por escritores maçons. Nota-se, nessa longa jornada, que os denominados heróis maçônicos surgiam e desapareciam dessa literatura ao sabor do tempo e das narrativas.

\section{PALAVRAS-CHAVE}

Ciências humanas; Lugares de memória; Narrativa historiográfica

\section{ABSTRACT}

Born as a mutual aid organization, Freemasonry would gain new contours, consolidating itself as an important sociability space in the second half of the 18th century and, institutionalized in Brazil at the threshold of the 19 th century. The brotherhood has expanded its ranks by incorporating into its organization important characters of its time, from high-ranking politicians to influential activists. This article presents the historiographic debate about the construction of the memories of Abolition based on the hypothesis that Freemasonry strategically chose to evoke the image of some characters in its history, in order to positively cement their experiences and supposed protagonism through contemporary Masonic narratives made by Freemason writers. It is noted in this long journey that the so-called Masonic heroes, emerged and disappeared from this literature in the light of time and narrative.

\section{KEYWORDS}

Human sciences; Memory places; Historiographical narrative 


\section{Introduçāo}

A maçonaria nasceu como organização de ajuda-mútua e, ao longo do tempo, constituiu-se também como espaço de sociabilidade, oferecendo rede de apoio político, social e simbólico a seus membros. É difícil atribuir à organização uma data de origem, uma vez que não há consenso historiográfico. Por convenção, muitos pesquisadores do tema adotaram como marcador histórico maçônico a Constituição de Anderson (GRAINHA 2011).

O documento é um compilado de registros maçônicos que reúne informações relativas aos direitos e deveres dos iniciados. A Constituição de Anderson foi elaborada na segunda metade do século XVIII. Com atuação transnacional, a organização tem atribuído a si mesma protagonismo nos principais eventos históricos ocorridos ao redor do mundo, como a Revolução Francesa (BARATA 2002).

O primeiro registro maçônica em território nacional data do ano de 1801, na cidade do Rio de Janeiro, quando se cria a Loja ${ }^{1}$ Maçônica Reunião (AZEVEDO 1996, p. 179). Conforme Marco Morel, a maçonaria constituiu-se com força no Brasil oitocentista, como expressão da expansão do espaço público (MOREL 2005). Ainda segundo o autor, após a Revolução Francesa, as associações do tipo maçônico "começaram, cada vez mais, a pleitear espaço" (MOREL 2005, p. 246). Na prática, isso significava que a organização se faria presente na imprensa, na política, na igreja e nas associações de modo geral.

Na província de São Paulo, a maçonaria desenvolveu-se tardiamente, comparada às demais localidades. A Loja Maçônica Inteligência foi a primeira a ser instalada em São Paulo, na cidade de Porto Feliz, em 1831. A consolidação da maçonaria na província paulista se daria na segunda metade do século XIX, com o crescimento expressivos de lojas (BARATA 1999). Nesse sentido, a presença da Faculdade de Direito na capital 
da província foi fundamental para promover a organização (BANDECCHI 1982).

Muitos estudantes foram recrutados para compor o quadro da organização, assim como representantes da imprensa, membros de outras associações e comerciantes (CASTELLANI 2000). O crescimento maçônico suscitaria maior participação maçônica na vida política e social do país.

Na segunda metade do século XIX, havia, por toda parte, maçons republicanos, abolicionistas, monarquistas, escravistas, uns mais atuantes e outros menos. Comprometidos com suas próprias agendas, alguns eram tributários de poderes de decisão, com representação no congresso; enquanto outros estavam envolvidos com o ativismo jurídico, lutando em defesa dos escravizados (RIBEIRO 2011). Como grupo heterogêneo, os maçons não conseguiram construir uma agenda unitária e coesa. A maçonaria ao longo de sua história colecionou cisões, conflitos e disputas, característica que colaboraria para seu declínio nas décadas subsequentes.

A perda de prestígio da maçonaria no século XX (MOREL 2008) seria progressiva e derradeira, após sucessivas perseguições e ameaças sofridas por décadas consecutivas. Diante do novo desenho político, a organização maçônica daria vasão a uma série de iniciativas, tais como a produção de uma historiografia que não apenas aproximava a história da organização aos eventos marcantes do país, mas se confundia com ela (CASTELLANI 2009).

A construção de monumentos-museu, a edificação de acervo com objetos dedicados à memória maçônica da abolição e a elaboração de narrativas maçônicas são partes integrantes do projeto de resgate da memória maçônica. Instrumentos essenciais à concepção da memória, mas incompletos, sem a consagração de seus heróis. Heróis que são tão importantes à construção da memória, quanto os símbolos e as práticas cultuados nos cerimoniais e rituais também o são, como 
bandeiras e indumentárias. De acordo com Paulo Miceli, o herói cria a perspectiva de que,

magicamente, só ele pode fundir todas as múltiplas partes que compõem, na realização de um ideal de libertação e emancipação de um país, de uma classe social, de uma etnia, de grupos religiosos e de uma infinidade de instituições e agrupamentos sociais, criados e mantidos por interesses e intenções igualmente múltiplos e quase nunca transparentes (MICELI 1994, p. 12).

Imbuído por esse sentimento, a maçonaria paulista zelava pela evocação de um herói capaz de incutir na memória maçônica da abolição uma representação profícua de si mesma. Nesse sentido, houve larga mobilização com o fito de transformar seus personagens em potenciais candidatos ao papel de herói maçônico. O esforço da promoção desses candidatos, entretanto, não seria tarefa simples, uma vez que poucos Irmãos reuniam as qualidades necessárias ao desempenho do pretendido papel de herói.

Neste artigo, investiga-se o papel do herói na construção da historiografia maçônica da abolição em São Paulo. Na primeira parte, realizou-se uma análise dos caminhos percorridos pela maçonaria paulista na escolha de Luiz Gama como o principal personagem da historiografia maçônica. Na segunda, foram considerados os recursos e esforços adotados pela organização para vincular a imagem do abolicionista à historiografia maçônica. Por fim, na terceira parte, os olhares se voltaram para o cemitério da Consolação, consolidado pela maçonaria como um importante espaço dedicado à construção da historiografia maçônica.

\section{A criaçāo dos herōis maçônicos na história da aboliçāo em Sāo Paulo}

O processo de fabricação do herói depende da confluência de diversos fatores, dentre eles as "condições de criação e 
recriação" (MICELI 1994, p. 12). Conforme Paulo Miceli, o herói não pode ser criado ou recriado com base em virtudes e qualidades incompatíveis com o tempo e as circunstâncias, tampouco pode distanciar-se do discurso pregado pelo grupo empenhado na validação de sua imagem.

Em meados do século XIX, forjava-se um modelo de herói ajustado às novas transformações sociais e econômicas vigentes no continente europeu. Esse conjunto de mudanças provocaria a emergência de um novo modelo de sociedade, fundado na chamada modernidade, paradigma marcado pela ascensão e difusão das ideias liberais, consagrada no pensamento igualitário e democrático, em oposição à religião, aos costumes, aos privilégios de classe e às monarquias absolutistas.

Todas essas experiências vividas pelas classes subalternas em suas múltiplas dimensões inspirariam a criação de um modelo de herói, então reproduzido nas narrativas literárias modernas. Na concepção de Walter Benjamin, "o herói era o verdadeiro tema da modernidade" (BENJAMIM 1975, p. 24) e, como símbolo dela, deveria refletir o desejo por justiça e igualdade. Desse modo, entrava em cena o herói moderno encarnado na figura do homem comum oriundo das massas, do povo, das multidões.

A virtude desse herói residia em sua coragem, em seu sacrifício. O herói moderno não se alienava diante dos problemas sociais, sacrificava a própria vida em nome de uma causa social, lutava pela sobrevivência e pela destruição de um modelo social opressivo.

Sob o signo do herói moderno, forjado no final do século XIX, a maçonaria destacaria de suas fileiras figuras que pudessem encarná-lo em suas narrativas. Nomes como os de José Bonifácio de Andrada e Silva, Joaquim Nabuco, Luiz Gama, Rui Barbosa e Antonio Bento surgiriam como candidatos ao posto. 
Joaquim Nabuco era um forte candidato ao papel de herói, uma vez que, nas últimas décadas de vigência da escravidão, havia se tornado uma voz importante no Parlamento e um respeitável articulador de ações abolicionistas. Ao lado de seus correligionários André Rebouças e José do Patrocínio, Nabuco arquitetou a criação da Fundação da Sociedade Brasileira contra a Escravidão, em 1880, uma organização projetada para funcionar como uma "versão brasileira da The British and Foreign Anti-Slavery Society" (ALONSO 2007, p. 189).

As múltiplas memórias construídas em torno da imagem do abolicionista limitavam-se, contudo, às perspectivas de eleválo ao posto de herói da abolição maçônica de São Paulo. Sua imagem havia se fragmentado. Conforme Ângela Alonso, (2007 p. 160), nas celebrações fúnebres realizadas em memória de Joaquim Nabuco, sua figura nem sempre esteve vinculada ao abolicionismo. Em Washington, cidade onde faleceu, exaltou-se a imagem de diplomata, legítimo representante da aristocracia.

Na cidade do Rio de Janeiro, a cerimônia fúnebre voltou-se para a construção de sua figura como político monarquista liberal. Só no Recife, sua cidade natal, onde foram depositados seus restos mortais, sua memória esteve atrelada profundamente à abolição e forjou-se uma imagem de líder popular de Nabuco. Lá, fora recebido por "marinheiros descendentes de escravos" (ALONSO 2007 p. 15) receberam o corpo do falecido que seguiu em cortejo pelas ruas da cidade, acompanhado por populares. A imagem de líder popular do abolicionismo construída em Recife não se transferiria para outras partes do país (ALONSO 2007 p. 15).

A maçonaria teria grandes dificuldades em colar a imagem de Nabuco à memória da abolição maçônica paulista. Afinal, em São Paulo, Joaquim Nabuco seria lembrado apenas como estudante da Faculdade de Direito, de origem aristocrática, com breve passagem pela maçonaria. Essa imagem o qualificava para ocupar um lugar na historiografia da abolição, mas não 
para assumir a posição de herói supremo da organização, ainda que em sua lápide houvesse clara alusão a sua participação no processo abolicionista.

Pouco mais identificado com as massas que Joaquim Nabuco, a imagem do paulista Antonio Bento conteria as qualidades indispensáveis para ocupar o lugar de herói da memória maçônica da abolição paulista, uma vez que era visto como sucessor de Luiz Gama na causa abolicionista. Na historiografia da abolição, seu nome esteve associado às ações ilegais, então desenroladas na fase final da luta contra a escravidão, ainda que tivesse se dedicado também às ações de manumissão à maneira de Luiz Gama (AZEVEDO 2010).

Segundo Alexandre Ferro Otsuka (2015), a historiografia da abolição construiu uma imagem ortodoxa de Antonio Bento, assentada excepcionalmente nas práticas ilegais, ou seja, na fuga de escravizados. Essa dimensão subversiva de suas ações teria se sobressaído em relação às outras atividades perpetradas pelo abolicionista, tais como a de jornalista e advogado. Otsuka enumera dois motivos que teriam determinado a construção de uma única imagem de Antonio Bento. A primeira delas resultava da falta de documentação imprescindível que permitisse uma análise mais abrangente a respeito desse personagem, e a segunda decorria da vigência de uma historiografia que havia se debruçado sobre um mesmo conjunto documental, predominantemente, fabricado por testemunhos e relatos de memorialistas abolicionistas ${ }^{2}$ (OTSUKA 2015).

A visão romantizada dos estudos memorialistas sobre a abolição em São Paulo e o papel desempenhado por Antonio Bento no processo abolicionista, produzidas algumas décadas depois da abolição, de acordo com Otsuka, ofuscaram outras perspectivas analíticas que se voltassem para a sua vida profissional depois de seu retorno para a cidade de São Paulo em 1877.

Essas interpretações consolidadas na historiografia da abolição, na perspectiva de Otsuka, demonstravam que Antonio
2 Grupo que afirmava ter ativamente participado ações lideradas por Antonio Bento e sobrevalorizado a atuação do maçom e dos caifazes. O Movimento dos Caifazes foi organizado por Antônio Bento de Souza e Castro. Os membros desse grupo organizavam fugas coletivas no final do século XIX, ou "roubavam os escravos de seus senhores" para enviálos ao quilombo do Jabaquara na cidade de Santos. 
Bento era uma figura subversiva e radical, tal concepção historiográfica, construída em torno do maçom, provavelmente não era bem vista pelos pesquisadores maçons.

Vale ressaltar que nos primeiros estudos produzidos pela literatura celebrativa na década de 1970, Antonio Bento sequer foi mencionado. A presença do abolicionista nas narrativas maçônicas foi incorporada somente em 1981(CASTELLANI 1981, p. 56), no texto produzido por José Castellani apresentado no Congresso Maçônico Internacional da História e Geografia dedicado à celebração do centenário da abolição. Na ocasião, o escritor José Castellani apresentou o artigo intitulado Antonio Bento: um nome esquecido no movimento abolicionista (CASTELLANI 1981, p. 12). Tempos depois, o autor lançaria - livro Os maçons e a abolição da escravidão, no qual daria relevo à trajetória do abolicionista (CASTELLANI 2000, p. 257).

A ausência temporária de Antonio Bento na historiografia maçônica deveu-se, provavelmente, ao próprio contexto de produção dessa literatura celebrativa. Entre as décadas de 1970 e 1980, auge de produção das narrativas maçônicas, o país vivia os anos mais difíceis do regime de exceção e a maçonaria como organização civil não ficaria imune à intervenção e vigilância do governo33 (CARVALHO; CASTELLANI 2009, p. 257).

A perseguição a maçonaria, vista como órgão de infiltração comunista, imprimia um sentido de reserva sobre os personagens que poderiam ou não ser cultuados naquele contexto. A imagem de subversivo construída pela historiografia da abolição em torno de Antonio Bento poderia facilmente ser associada a ideologias e lideranças de esquerda, motivando, portanto, censuras e novas intervenções do governo. Esse elemento sozinho evidentemente não seria suficiente para explicar completamente o ostracismo temporário de Antonio Bento dos escritos maçônicos.

Outro aspecto de rejeição da figura de Antonio Bento associava-se ao próprio interesse da organização em construir uma memória maçônica da abolição assentada na concepção
3 Em 1971, o governo indiciou o grão-mestre do Grande Oriente de São Paulo, Danylo José Fernandes Grande, por suspeita de "infiltração comunista". Embora nada tivesse sido provado contra grão-mestre e obediência, no entanto, a experiência de intervenção na organização, de certo modo, deixaria os escritores maçons em alerta. 
de que a extinção da escravidão deveria ter sido encaminhada de forma lenta e gradual, e a imagem de Antonio Bento, em contrapartida, estava atrelada às ações ilegais, ao caos e à desordem, perpetradas pelo maçom na companhia de seus companheiros caifazes, apoiada na "rede de fugas assistidas" (OTSUKA 2015, p. 99).

Escolher Antonio Bento como herói da memória da abolição paulista, neste momento, significava atribuir à instituição maçônica características obscuras, subversivas e ilegais. Tais predicados imputados a ele, como sublinhou Alexandre Ferro Otsuka, permearam toda a historiografia da abolição, ocultando outras importantes dimensões da atuação legal do abolicionista (OTSUKA 2015).

Enquanto a imagem de Joaquim Nabuco estava associada à aristocracia e à monarquia, a figura de Antonio Bento era sinônimo de caos, desordem e subversão. Portanto, nem Joaquim Nabuco nem Antonio Bento poderia ser alçado como símbolo supremo da historiografia maçônica em São Paulo.

Nessa disputa, o candidato com maior potencial para desempenhar o papel de herói da historiografia maçônica da abolição seria, portanto, o baiano Luiz Gama. O abolicionista reunia todos os atributos necessários à construção da figura do herói. Sobressaiu-se entre os demais candidatos por ser o único maçom a experimentar a escravidão na pele. Como "homem de cor", sua presença no quadro maçônico imprimia um sentido genuinamente fraternal e igualitário à organização, isentando-a, ao mesmo tempo, de ser portadora de práticas discriminatórias de natureza racial e/ou social contra "Irmãos de cor" (AZEVEDO 2010).

Membro histórico da Loja América, Gama demonstrou talento no campo jurídico, defendendo a liberdade de africanos ilegalmente escravizados, resguardando os cativos do abuso praticado por seus senhores. Ainda que tenha fracassado em algumas ações de manumissão, tais práticas Ihe deram a devida visibilidade para além das fronteiras da cidade. Advogados de 
outras cidades buscaram por sua orientação jurídica (PINTO 2014, p. 70), ao passo que africanos ilegalmente escravizados de outros municípios da província paulista seguiam com destino a São Paulo, depositando suas esperanças de liberdade nas mãos do advogado provisionado4.

Essa era apenas uma das facetas do abolicionista que também dedicou parte de seu tempo em colaboração com a imprensa paulista e carioca (Correio Paulistano, O Ipiranga, Radical Paulistano, Gazeta do Povo, O abolicionista, Gazeta da Tarde), manifestando-se contra a escravidão, o poder da Igreja católica, o poder moderador e a monarquia. Luiz Gama reservaria ainda tempo para dedicar-se a sua própria folha, o domingueiro Diabo Coxo (1864-1865), considerado o primeiro jornal ilustrado de caricatura de São Paulo (FERREIRA 2011). Gama demonstrou gosto e afinidade pela escrita ainda em 1859, quando publicou seu primeiro e único livro de poemas, Primeiras Trovas Burlescas, em São Paulo.

A trajetória do maçom abolicionista escravizado pelo pai na Bahia e que morreria como um líder abolicionista popular na província de São Paulo, aclamado por toda a sociedade paulista, não poderia ser ignorada pela maçonaria paulista interessada em fabricar um herói maçônico capaz de assegurar a recuperação da imagem da organização.

Como se observa em diferentes registros, a morte de Luiz Gama gerou forte comoção na cidade de São Paulo. As homenagens ao maçom não pararam de acontecer nos meses e anos seguidos a sua morte. A mobilização coletiva atingia diferentes setores sociais:

Tendo resolvido solenizar o primeiro aniversário do passamento do Grande cidadão Luiz Gama, por meio de um sarau literário que terá lugar na noite do 24 do corrente mês, no teatro São José e de uma procissão cívica que se deve realizar no domingo após 26 do corrente vem convidar a distinta loja Piratininga, a comparecer na corporação, com o seu estandarte, para tomar parte, não só na dita sessão como igualmente no respectivo
4 Luiz Gama defendeu muitos africanos oriundos de outras cidades como 0 escravo Jacinto, fugido de seu suposto senhor (Antonio Gonçalves), alegando ser submetido à escravidão ilegal. 
cortejo. Luiz Gama representa o desejo popular de São Paulo, é uma glória nacional como exemplo venerando do civismo, e é um benemérito da humanidade, combatente heroico de uma das campanhas formidáveis do século. Cantamos com brilhante concurso das corporações populares de São Paulo. No aniversário de passamento de Luiz Gama, não o solenizamos como uma data de luto. A nossa festa significa a homenagem justa a um grande nome. (Ata da Loja Piratininga 19 de agosto de 1883).

Uma série de homenagens, amplamente registradas em documentos maçônicos, relatos e testemunhos garantiriam as condições necessárias para a construção da memória maçônica da abolição. Em 24 de agosto de 1894, data de aniversário do passamento de Luiz Gama, membros da Loja Sete de Setembro, entres eles, Antonio Góes Nobre, em homenagem ao Irmão, articularam a criação de uma loja maçônica que recebeu o seu nome:

Decorrido algum tempo, como homenagem aos relevantes serviços prestados em vida para a emancipação dos escravos, lembrei-me de fundar uma Loja com seu nome, com o concurso dos obreiros das lojas (...), porém composta somente de homens pretos e já livres pela lei da alforria (...) assinada ela Princesa Imperial, na ausência do Imperador que havia seguido viagem para a Europa. Para a formação da Loja, iniciei 25 pretos, me afastei da mesma só aparecendo 2 anos [depois] (...) (FERREIRA 2001, p. 551).

Particularmente, os relatos e os testemunhos produzidos por contemporâneos de Luiz Gama ofereceriam os subsídios necessários à fabricação da figura do abolicionista como herói. A longa e romantizada cena de seu enterro, narrada pelo amigo Raul Pompéia repercutiria para além daqueles tempos. Publicado no jornal Gazeta de Notícias - "Última página da vida de um grande homem" -, o relato traduzia a dimensão que a morte de Luiz Gama havia alcançado na cidade: "Nunca houve coisa igual em São Paulo, dizia-se pelas esquinas"; "E o nome de Luiz Gama, coberto de bênçãos, corria de boca em 
boca. No posto de honra das alças do esquife sucedia-se toda a população de São Paulo" (Gazeta de Notícias 10 de setembro de 1882).

Raul Pompéia não foi o único a romancear o funeral de Gama, outros de seus contemporâneos seguiram na mesma direção, publicando cartas, poemas e artigos em homenagem ao abolicionista, como Rangel Pestana, "A morte de Luiz Gama"; Alfredo Cardoso de Abreu Peroba "A Luiz Gama"; Belarmino Indalécio de Sousa, "A memória de Luiz Gama"; Raimundo Correia, "Luiz Gama". Essas narrativas seriam usadas posteriormente como fonte histórica (FERREIRA 2011).

O artigo produzido por Rangel Pestana em homenagem a Luiz Gama, em 1882, seria reproduzido em 1930, cinquenta anos depois em outro jornal, reavivando a importância do maçom no processo abolicionista:

Luiz Gama, um grande talento, uma grande abnegação, saíra de condições inferiores e chegara a merecer consideração e estima não só em São Paulo como em todo o país. Seu nome alargava sempre o espaço que a popularidade enchia com a fama de seus atos de destemido e benemérito abolicionista e democrata. Junto do corpo inânime daquele negro ilustre por seus próprios feitos, que traduziam a energia de uma vontade inabalável, o esplendor de uma inteligência vigorosa, os contemporâneos, amigos de admiração e respeito. (...) Luiz Gama não era, pois um "vulto negro" que arvorando a bandeira do abolicionismo ameaçava cobrir de horrores a sociedade; era antes de tudo a imagem viva da caridade que não têm cores nem privilégios de nobreza. Tipo de heroísmo nas sociedades modernas, ele aparecia entre nós como o pai dos pobres, dos desprovidos dos favores da fortuna e das graças do poder. (A Província de São Paulo 21 de junho de 1930).

Reproduzido no jornal A Província de São Paulo na ocasião da celebração do centenário de nascimento de Luiz Gama, em 21 de junho de 1930, o artigo continha valores heroicos atribuídos à figura de Luiz Gama que não mudaram com o tempo. As virtudes imputadas por Rangel Pestana ao abolicionista 
("caridade", "popularidade", "pai dos pobres", "vulto negro", "negro ilustre", "destemido", "inteligência vigorosa") definiam uma concepção de herói moderno então forjado em meados no século XIX, que encontrou terreno fértil à sua manutenção e expansão no século $X X$.

Na concepção do herói moderno, Luiz Gama representava o homem real, era figura popular egressa das camadas desprivilegiadas, negro (como a maior parte da população), sem grandes ambições, movido pelo sacrifício, pela caridade, pela generosidade, pelo altruísmo, que lutou até o último instante de sua vida contra a opressão escravista. Essa era a imagem de Luiz Gama construída com base em relatos e narrativas de seus contemporâneos.

A biografia do abolicionista publicada pela primeira vez em 1881 por Lúcio de Mendonça no Almanaque Literário de São Paulo seria igualmente recuperada em inúmeras outras ocasiões no século XX. Em 1895, a história de Luiz Gama foi resgatada no livro de Tancredo Amaral, A história de São Paulo ensinada pela biografia dos seus vultos. Em 13 de maio de 1920 (data de celebração da abolição) o documento foi reproduzido pela primeira vez no jornal A Província de São Paulo; a segunda, na data do centenário de nascimento de Luiz Gama (21 de junho de 1930); depois replicado na Revista do Instituto Histórico Geográfico de São Paulo, em 1930; na Revista da Academia de Letras, em 1933; servindo ainda como principal fonte documental à elaboração do primeiro livro biográfico publicado por Sud Menucci sobre o abolicionista em 1938 (FERREIRA 2011, p. 256).

Alguns valores e virtudes atribuídos a Luiz Gama no passado sofreriam alterações de sentido e importância. A cor de sua pele provavelmente teve um peso maior na manutenção de sua imagem como herói no século XX do que no século XIX, já que no novo cenário social pós-abolição a ideia de construção da cidadania e da identidade nacional passava necessariamente pela temática racial nas décadas de 1920 e 1930. 
A negritude não foi um assunto diluído em sua biografia, pelo contrário, sua imagem não sofreu retoques, não esteve sujeita ao processo de branqueamento como sucedera com outros "homens de cor", como Machado de Assis (PINTO 2014, p. 154). Luiz Gama permaneceria imune ao branqueamento, posto que o abolicionista nunca negou sua negritude, pelo contrário, exaltou-a oportunamente, evocando sua ancestralidade africana em textos, cartas, artigos e poemas. Alguns deles publicados em seu livro, Primeiras Trovas Burlescas, de 1859, no qual o abolicionista inflava a sua negritude ("Negro sou" e "Quem sou eu") (FERREIRA 2011).

Os jornais e as revistas da época registraram a figura do abolicionista, conservando sua fisionomia de "homem de cor". Sua imagem foi reproduzida sem grandes alterações, provavelmente por ter sido largamente registrada ao longo de toda a segunda metade do século XIX e primeiras décadas do século XX. Seu rosto havia estampado as páginas dos principais jornais do período. Reproduzido, ainda, no pincel do cartunista italiano Ângelo Agostini (1867 e 1882) e fotografado por Militão Augusto de Azevedo, um dos principais retratistas da época.

Luiz Gama enquadrava-se perfeitamente no protótipo de herói porque sua imagem comportava um "modelo coletivamente valorizado" (CARVALHO 1990, p.55). "Homem de cor" que erigiu bandeiras políticas importantes - a luta pela abolição e pela república (AZEVEDO 1999). Figura popular que transitava com tranquilidade entre as distintas camadas sociais, desde os grupos remediados, pobres e marginalizados (livres pobres, forros e escravizados) até os mais elitizados da sociedade paulista.

Na disputa pelo lugar de herói na historiografia maçônica da abolição, certamente lançar a figura de Luiz Gama ao panteão dos heróis não demandaria grande esforço à organização, afinal a trajetória do morto fornecia o aporte necessário para a construção da imagem do herói moderno. 
Todos esses elementos associados à figura de Luiz Gama acabariam se sobrepondo à imagem de Joaquim Nabuco e de Antonio Bento. Conforme Paulo Miceli, "ao saltar de seu tempo, além da consagração póstuma, os heróis são condenados a trabalhar sempre e a dedicar sua vida (ou sua morte) para que "os homens" (possam ser) salvos de alguma coisa" (MICELI 1994, p. 25).

Nesse sentido, a imagem de Luiz Gama se prestaria ao "salvamento" da memória maçônica da abolição. Por essa razão, o Grande Oriente de São Paulo erigiu um busto em bronze em homenagem ao seu herói da abolição. O busto dedicado a Luiz Gama está exposto no hall de entrada do museu maçônico paulista.

\section{Usos do passado e a apropriaçāo da memória maçônica de Luiz Gama e de Antonio Bento.}

Na disputa pelo posto de herói da memória maçônica da abolição vê-se a figura do baiano Luiz Gama imperar sobremaneira em relação às imagens do paulista Antonio Bento e do recifense Joaquim Nabuco. A imagem de Luiz Gama não havia esvaído completamente com o tempo e, para os propósitos maçônicos de construção de uma historiografia que valorizasse a memória da organização, convinha consagrar Luiz Gama como herói. A figura do abolicionista imputava um sentido democrático, fraternal e igualitário à maçonaria paulista.

A comoção gerada com a morte de Luiz Gama seria o ponto de partida para a construção de uma literatura maçônica pautada na memória do abolicionista. De acordo com Carmen Mc Evoy, a orquestração dos grandes funerais fornece os subsídios essenciais à cristalização da imagem coletiva do morto, seguindo três etapas: primeiro, a morte inesperada; segundo, o abalo coletivo; e, por fim, a realização de um grande funeral. Essas fases estiveram presentes no processo de mitificação de Luiz Gama, morto em 1882. 
Conforme Mc Evoy "a morte de uma pessoa importante é um espetáculo com rasgos teatrais em si, manifestação evidente do poder simbólico que se intenta projetar sobre uma determinada comunidade" (EVOY 2006, p. 150).

O passamento de Luiz Gama representaria um divisor de águas no movimento abolicionista paulista. Após a sua morte, emergiria uma nova liderança, Antonio Bento, que embora tivesse preenchido em tese o vazio deixado por seu antecessor, não foi capaz de enterrar o espírito de Luiz Gama. A memória de Gama foi evocada em diferentes momentos como liderança simbólica à frente do movimento abolicionista. A sua imagem era vivificada por toda parte: nas conferências públicas abolicionistas, proferidas pelo amigo José do Patrocínio, na cidade do Rio de Janeiro, bem como nos discursos de seus correligionários Joaquim Nabuco, André Rebouças, José Mariano e João Clapp (ALONSO 2007, p. 180).

Nesse período, desenhava-se a mitificação da figura de Luiz Gama por meio das constantes celebrações realizadas pelo seu passamento. Associações como Club dos Girondinos, Centro Abolicionista de São Paulo e Caixa Emancipadora Luiz Gama organizaram uma maratona de homenagens ao finado com saraus, festas, cortejos e missas. Em sua homenagem, a Loja América instalou uma placa cravejada com o símbolo da organização no túmulo do falecido em 1883 (BANDECCHI 1982, p. 83).

Os recursos à evocação de sua memória pareciam inesgotáveis. Os cortejos, com destino ao Cemitério da Consolação, entre os anos de 1883 e 1884, transformariam o espaço em um verdadeiro santuário. Nesses dois anos, consecutivamente, as celebrações foram encerradas ao pé do túmulo do abolicionista (FERREIRA 2001. p. 520-521).

Conforme Cecília Helena de Salles Oliveira, os túmulos, assim como os monumentos e os rituais celebrativos colaboravam para "gerir a memória e impedir que o "esquecimento" semeasse a "morte dos imortais" (OLIVEIRA 2011, p. 198). O 
ritual de visitação criado em torno da lápide do abolicionista se convertia em tradição que tinha o objetivo de "inculcar certos valores e normas de comportamento através da repetição, o que implica, automaticamente, uma continuidade em relação ao passado" (HOBSBAWM; RANGER 2012, p. 9).

A tradição de visitação ao túmulo de Luiz Gama nos aniversários de seu passamento representava não apenas uma forma de celebração da memória do morto, mas, sobretudo, uma tentativa de demarcar um lugar à prática do protesto silencioso e simbólico contra a escravidão, num contexto marcado pela desconstrução do sistema escravista, caracterizado por fugas em massa de cativos (FERREIRA 2001).

Luiz Gama havia morrido no auge da luta abolicionista situação que colaborou com a mitificação de sua figura. Até 1888, a imagem do maçom se tornou importante no debate antiescravista, servindo como fonte de inspiração aos seus correligionários, mas pouco tempo depois de sancionada a Lei Áurea, a figura do abolicionista disputaria atenção com a imagem da Princesa Isabel.

Conforme Flávio Gomes, a simpatia dos populares, particularmente dos libertos, pela monarquia e pela família real, se deveu ao fato de uma parcela significativa dos republicanos serem em sua maioria formada por ex-senhores e fazendeiros escravocratas "insatisfeitos com a libertação imediata dos escravos" (GOMES 2005, p. 20). Muitos libertos temiam que a mudança do regime representasse a sua reescravização.

No contexto da abolição, as ações populares antiescravistas em São Paulo, elaboradas pelas forças populares manifestavamse em todas as partes, como salientou Maria Helena Machado,

a atuação abolicionista não se limitava às lutas forenses - nos anos mais adiantados da década, a disciplina do populacho abolicionista e a turbulência das ruas, onde, muitas vezes, a participação dos negros se mostrava majoritária, povoavam as ruas da cidade de São Paulo. (MACHADO 1994, p. 156). 
A articulação política negra, segundo Flávio Gomes, vinha se desenhando nos anos finais da escravidão, através de ações individuais (fugas de escravos) e por meio de mobilizações coletivas, identificadas na formação da Guarda Negra, em associações, nos clubes recreativos, na constituição da imprensa negra (GOMES 2005, p. 29), bem como demonstrada pela atuação das irmandades negras, no final do século XIX e início do XX (QUINTÃO 2002), redutos onde a memória de Luiz Gama ressurgiu com força.

Inspirados em associações e clubes criados por imigrantes, os ativistas negros se organizavam não apenas com a intenção de celebrar o 13 de maio, mas também com o intuito de denunciar e combater a exclusão social e racial vivida pela população, na luta por terra, autonomia, moradia e salário, em fins do XIX e princípio do século XX (GOMES 2005, p. 12).

Os jornais Á Pátria (1889) e O progresso (1899) expressavam as expectativas dos libertos em relação ao seu lugar na sociedade. Considerados os periódicos mais antigos a circularem em São Paulo, teriam inaugurado o debate por direitos e cidadania na imprensa negra (PINTO 2010). Traziam em suas páginas formatos e estéticas distintas, mas detinham pautas de reivindicações semelhantes, dedicadas a um público específico, eram "jornais feitos por negros; para negros; veiculando assuntos de interesse das populações negras" (PINTO 2010, p. 19-20), também preocupados em assegurar em suas folhas espaço para dedicar-se a memória da abolição, trazendo a luz recorrentemente a figura de Luiz Gama.

Na década de 1920, o jornal O Clarim da Alvorada (19241932), seguindo na esteira da imprensa negra produzida no final do século XIX e início do XX, esforçava-se, com seus parcos recursos, na luta para a constituição de uma memória positiva do negro na sociedade, visando incorporá-lo como parte integrante da identidade nacional em construção (FRANCISCO 2013, p. 50). 
A desejada "segunda abolição" teria como ponto de partida o apelo ao resgate simbólico da memória dos abolicionistas negros, Luiz Gama e José do Patrocínio. Ambos vistos como "redentores da raça" (FRANCISCO 2013, p. 84) e que, por isso, deveriam ser evocados e celebrados como personagens caros à construção da história dos negros. As edições do jornal O Clarim da Alvorada, referentes aos meses de maio e setembro, foram dedicadas à celebração da abolição. No mês de maio, os artigos homenagearam os abolicionistas e a Princesa Isabel e, no mês de setembro, festejariam a Lei do Ventre Livre. Conforme Flávio Thales Ribeiro Francisco, "o abolicionismo retratado pelo periódico negro não era compreendido somente como um movimento que lutou pela libertação dos escravos, mas como aquele que abriu as portas para a integração do negro à sociedade brasileira" (FRANCISCO 2013, p. 87).

O Clarim da Alvorada, uma das folhas que mais tempo circulou na imprensa negra paulista, lançou luz à figura de Luiz Gama, ao promover a recuperação da tradicional visitação ao túmulo do abolicionista, iniciada em 1883 (FERREIRA 2011, p. 120). Na celebração do dia 13 de maio de 1929, os articulistas do jornal O Clarim da Alvorada realizaram uma procissão - cujo percurso incluía uma breve parada na Praça João Mendes. No local, realizaram debates sobre os problemas sociais enfrentados pela população negra, para, na sequência, seguirem com destino final ao Cemitério da Consolação - com o intuito de celebrar a data da abolição sob os túmulos dos abolicionistas Luiz Gama e Antonio Bento (FRANCISCO 2013, p. 89).

O ato simbolizava a apropriação da representação de Luiz Gama pelas organizações negras. As visitações a seu túmulo ganhariam um novo significado: se antes $r$ epresentavam a luta contra a escravidão, no período pós-abolição, a visita ao túmulo significaria a luta dos negros pela integração social e a luta simbólica por uma "segunda abolição". 
Conforme Carmen Mc Evoy, o impacto dos rituais fúnebres sobre o imaginário coletivo no século XX emergiu com força devido à concepção do binômio "corpo-memória" (EVOY 2006, p. 35), termo que, segundo a autora, era capaz de mobilizar o imaginário coletivo no incremento da consagração da memória de personagens importantes. Segundo Ana María Stuven, o ritual fúnebre cumpria a função não apenas de vivificar a memória do morto, mas servia também como manobra de grupos interessados em mobilizar a imagem do falecido com objetivos políticos, assim como ocorreu com a imagem de Luiz Gama e, em menor proporção, com a de Antonio Bento.

Para as organizações negras, emergentes na década de 1920, a procissão ao túmulo na data de celebração do 13 de maio não bastava. Os ativistas negros desejavam criar outros espaços de resistência. Daí nasceu um movimento civil, composto pelo mesmo grupo de ativistas negros da folha O Clarim da Alvorada, com o intuito de edificar o busto em homenagem a uma personalidade negra (SIEGEL 2007, p. 315-347). O abolicionista se transformaria na imagem do herói negro, símbolo da luta pela abolição, e fonte de inspiração a todos os seus Irmãos de "cor" em sua luta por cidadania.

A construção do busto de Luiz Gama abolicionista edificado em bronze, no largo do Arouche, em 1931, cumpria o papel de impor a presença do abolicionista no espaço público. Vale lembrar que a consagração do abolicionista não romperia com a tradição das visitações ao túmulo.

A edificação do rosto de Gama à apreciação pública também tinha o propósito de apropriação da imagem do morto pelas organizações negras, como exprimia a própria inscrição cunhada no busto "A Luiz Gama por iniciativa do progresso, homenagem dos pretos do Brazil" (FERREIRA 2001, p. 534). A presença de membros das Lojas maçônicas Piratininga e Luiz Gama na inauguração do busto de Luiz Gama representava a primeira tentativa pública de apropriação maçônica perpetrada pela organização em parceria com os ativistas negros. 
"Em 12 de agosto de 1930" havendo a nossa augusta loja resolvido em sessão de ontem comemorar o aniversário do falecimento do nosso inesquecível patrono e grande abolicionista "Luiz Gama" com uma sessão solene, na qual deve ser também inaugurado seu busto, no dia 25 do corrente mês, é, como o templo ordinário não mesmo para maior brilho da referida solenidade, vimos pela presente, solicitar dessa loja coirmã, a fineza de conceder-nos permissão para realizar a referida sessão no templo grande. Certos de que essa Benemérita coirmã nos dispensará mais esta atenção, apresentamos a todos os distintos obreiros que abrilhantam as suas coleções os nossos agradecimentos. Por ordem da loja Luiz Gama (Solicitação urgente). (Arquivo Loja maçônica América).

A mobilização dos ativistas negros em torno do resgate da memória de Luiz Gama, colaboraria para reavivar a imagem do abolicionista na historiografia maçônica tempos depois. O mesmo não aconteceria com a figura de Antonio Bento, que, embora tivesse sido lembrado no pós-abolição como personagem central na luta abolicionista, não estaria respaldado por um grupo social.

Enquanto a imagem de Gama ressurgia como referência na historiografia da abolição, a representação da redentora dos escravos, Princesa Isabel, declinava lentamente (DAIBERT 2004, p. 227), abrindo caminho para a emergência de novos e antigos símbolos da memória da abolição. Desde o início do século $X X$, as organizações negras se mobilizaram em busca de novas representações que pudessem ser vinculadas à historiografia da abolição, e ao mesmo tempo, ser referência positiva na luta por cidadania da população negra, ex-escrava e descendente de escravizados. Assim, ao lado de Luiz Gama, emergiu a representação da Mãe Preta, símbolo da escrava ama de leite "frequentemente citada na imprensa negra como um símbolo, não apenas dos sacrifícios que os negros haviam feito pelo Brasil, mas também dos fortes laços que uniam europeus e afro-brasileiros em um destino comum" (ANDREWS 1998, p. 336). 
A edificação do monumento em homenagem à Mãe Preta resultou de uma ampla mobilização iniciada ainda em 1926, quando o jornalista Cândido de Campos, redator do jornal carioca $A$ Notícia, encetou a campanha que receberia o largo apoio de ativistas negros, congregando "desde pessoas mais abastadas às mais humildes" (SIEGEL 2007, p. 316), como jornalistas, religiosos, estudantes, militares e artistas.

$\mathrm{Na}$ cidade de São Paulo, a luta pela edificação do monumento à Mãe Preta seria encampada pelo jornal O Clarim da Alvorada. Para o editor do jornal, José Correia Leite, a Mãe Preta era uma espécie de "mãe carnal das mães negras" e para as elites brancas "símbolo de nostalgia" (SIEGEL 2007, p. 322). Independentemente das interpretações e dos sentidos dados ao monumento, o fato era que todos eles convergiam na mesma ideia de "adotar uma retórica da harmonia racial" (SIEGEL 2007, p. 329), ou seja, na direção de um significado de pacificação.

Essa larga mobilização, com o intuito de edificação do monumento em homenagem à Mãe Preta, todavia, se concretizaria muito tempo depois, em 1955. Até 1960, o monumento foi celebrado na data de sanção da Lei do Ventre Livre, em 28 de setembro. Mas, a partir da década de 1960, com a articulação de novos grupos, ligados ao culto do candomblé, em São Paulo, a representação passaria a ser celebrada na data do 13 de maio (ANDREWS 1998, p. 331).

Ao lado de Luiz Gama e da Mãe Preta (ver Figura 5.5) surgiria a figura de Zumbi dos Palmares, fruto da emergência das correntes marxistas da década de 1960. Zumbi foi trazido à cena por historiadores marxistas como Clovis Moura, Edson Carneiro e Décio Freitas, ligados à militância negra (REIS 2004, p. 3).

Eles foram os responsáveis pela valorização da figura do herói de Palmares, até então adormecida. Conforme Andressa Merces Barbosa dos Reis, em 1859, o termo Zumbi era considerado apenas um título, sinônimo de rei do Quilombo 
(REIS 2004, p. 33), somente nas primeiras décadas do século XX seriam "moldadas às bases para que a historiografia de Palmares e de Zumbi pudessem ser desenvolvidas e apropriadas pelos autores marxistas" e cristalizadas nas décadas de 1980 e 1990 (REIS 2004, p. 72).

De acordo com Andrews, a emergência da figura de Zumbi dos Palmares como guerreiro, líder e herói negro incidiu num contexto em que as organizações negras no fim da década de 1960 procuravam novas representações para a celebração do 13 de maio, haja vista que a figura da Mãe Preta passou a ser questionada como representação ideal, passando a ser vista como um símbolo da submissão e da acomodação dos negros à escravidão (ANDREWS 1998, p. 336).

A partir da década de 1970, os descontentamentos das organizações negras se intensificaram não mais apenas no desejo de encontrar novas representações, mas também de encontrar uma data alternativa ao 13 de maio, uma vez que os ativistas negros não se identificavam mais com ela (RIOS 2014 , p. 12). Na concepção das organizações negras, o 13 de maio estava fortemente atrelado à imagem da Princesa Isabel, remetendo à ideia de salvação negra pelas mãos de uma mulher branca, imprimindo um sentido de caridade e não de conquista e luta. A data deixava transparecer a passividade do povo negro na luta pela abolição. Desse modo, como alternativa à superação dessa ideia, emergiu a figura de um novo herói: Zumbi dos Palmares, personagem capaz, na compreensão das organizações negras, de representar o protagonismo negro na escravidão.

No centenário da abolição da escravidão em 1988, as disputas pelas representações se acirraram. De um lado, setores conservadores e membros da elite ligados aos descendentes da família Imperial lutavam pela manutenção da data do 13 de maio e, do outro, os movimentos negros, apoiados por segmentos educacionais, reivindicavam a data de 20 de novembro como legítima para celebrar a abolição (DAIBERT 2004, p. 251), a data que celebrava a morte do Zumbi dos Palmares. 
O movimento em favor da mudança da data ganhou corpo e explodiu em manifestações, com destaque, a organizada pela Secretaria da Educação da Prefeitura Municipal do Rio de Janeiro. O manifesto contaria com a adesão de estudantes de escolas públicas que marcharam pelas ruas da cidade e compareceram ao memorial dedicado a Zumbi "ao som de música "funk", alternada pelo samba-enredo da Mangueira de 1988, "Cem anos de Liberdade: Realidade ou ilusão?" (DAIBERT 2004, p. 251).

Desde 1978, o movimento negro, que vinha se reconstruindo nos anos finais do regime militar (RIOS 2014, p. 15), passou a celebrar o fim da escravidão na data do 20 de novembro e não mais no 13 de maio (ARAÚjo 2015, p. 470). Na cidade de São Paulo, por exemplo, a nova data teria sido incorporada oficialmente ao calendário somente em 2003, após a sanção da Lei Municipal paulista n013.707/04. A oficialização da nova data para a celebração da abolição e luta contra a opressão da população negra não excluiria dos festejos a figura de Luiz Gama, cujas celebrações no túmulo, antes realizadas no 13 maio, passariam a ocorrer em 20 de novembro.

O projeto de recuperação maçônico comportava iniciativas diversas que iam desde a produção historiográfica até a edificação de espaços onde a organização pudesse ser vista e valorizada em diferentes contextos. Em todos esses empreendimento, a imagem de Luiz Gama teve papel central.

\section{Consideraçōes Finais}

Na segunda metade do século XIX, a maçonaria constituiuse como interlocutora privilegiada dos principais debates da cena político-social do Brasil Império. Contudo, no que se refere ao tema da abolição, manteve-se dividida. Enquanto uma parcela dos irmãos aderia ativamente as ações abolicionista; a outra parte manteve-se fiel à manutenção do sistema escravista. 
Com o fim da escravidão e a sucessiva perseguição sofrida pela maçonaria durante os governos de Getúlio Vargas e dos militares, a organização entendeu que o caminho mais acertado à recuperação de sua história se daria por meio da produção robusta de narrativas e pela construção e conservação de símbolos. A maçonaria precisou atualizar suas narrativas em diferentes tempos, evocando alguns personagens, ocultando outros, conforme as circunstâncias históricas necessárias a sua representação ou ressignificação.

Quando a maçonaria lançou luz sobre personagens centrais do debate abolicionista com passagem pela organização pretendeu, com isso, dar sentido de unidade às experiências passadas, sobretudo em relação à abolição da escravidão, tema para o qual a organização foi incapaz de construir uma agenda unificada, haja vista que parte de seus membros era proprietária de escravos e o debate abolicionista teria suscitado apenas divisões e disputas internas.

Ao eleger seus heróis abolicionistas, a historiografia maçônica revisionista construiu novas narrativas sobre seu passado com o intuito de deixar à penumbra os irmãos declaradamente escravistas. A literatura maçônica recente não poderia incorporar em sua historiografia personagens que haviam pactuado com a escravidão.

A historiografia maçônica estava comprometida em construir narrativas que transformassem a organização em agente protagonista do movimento abolicionista. Para isso, precisou, por um lado, negar a presença de escravistas em seus templos e, do outro, convocar os membros abolicionistas capazes de legitimar a existência de uma suposta agenda antiescravista que lhe atribuísse protagonismo no movimento. Nesse sentido, eleger heróis entre os maçons se tornaria um empreendimento cirúrgico.

Luiz Gama foi peça fundamental das narrativas maçônicas, pois representava a face mais popular e ativa do movimento abolicionista, ativista, negro e maçom, foi um dos personagens 
centrais da historiografia da abolição. Sua importância na historiografia, no entanto, não se encerrou na cena abolicionista ecoou para além do tempo, sua imagem foi incorporada pelas lideranças negras em diferentes tempos e contextos.

Atualizada, a figura de Luiz Gama ganhou novos contornos e foi ressignificada também nas narrativas maçônicas, dando a ela ares populares, consolidando-a como espaço de sociabilidade, essencialmente democrático, coesa e garantidora da participação de "homens de cor". 


\section{REFERÊNCIAS}

ALONSO, Angela. Joaquim Nabuco: os salões e as ruas.

São Paulo: Companhia das Letras, 2007.

ANDREWS, George Reid. Negros e brancos em São Paulo. Tradução: Magda Lopes. São Paulo, Bauru: EDUSC, 1998.

ARAúJO, Ana Lucia. Memória pública comparada da emancipação e da abolição da escravidão: Abraham Lincoln e princesa Isabel. In: MACHADO, Maria Helena P. T.; CASTILHO, Celso Thomas (Orgs.). Tornando-se Livre: agentes históricos e lutas sociais no processo de abolição. São Paulo: Editora da Universidade de São Paulo, 2015. p. $451-473$.

AZEVEDO, Célia Maria Marinho. Maçonaria: história e historiografia. Revista USP, dez/fev. n. 32, p. 178-189, 1996/97.

AZEVEDO, Elciene. Orfeu de carapinha: a trajetória de Luiz Gama na imperial cidade de São Paulo. Campinas, São Paulo: Editora da Unicamp, Centro de Pesquisa em História Social da Cultura, 1999.

AZEVEDO, Elciene. O direito dos escravos: lutas jurídicas e abolicionismo na província de São Paulo. Campinas, São Paulo: Editora da Unicamp, 2010.

BANDECCHI, Brasil. A bucha, a maçonaria e o espírito liberal. São Paulo: Editora Parma, 1982.

BARATA, Alexandre M. Luzes e sombras: a ação da Maçonaria Brasileira (1870-1920). Campinas, São Paulo: Editora Unicamp, Centro de Memória Unicamp. (Coleção Tempo e Memória), 1999. 
BARATA, Alexandre M. Maçonaria, sociabilidade ilustrada e independência do Brasil. Tese de Doutorado. Universidade Estadual de Campinas. Instituto de Filosofia e Ciências Humanas. Unicamp, São Paulo, 2002.

BENJAMIM, Walter. A modernidade e os modernos. Rio de Janeiro: Tempo Brasileiro. Tradução Heindrun Krieger Mendes da Silva, Arlete de Brito e Tânia Jatobá, 1975.

CARVALHO, José Murilo de. A formação das almas: o imaginário da república no Brasil. São Paulo: Companhia das Letras, 1990.

CASTELLANI, José. Os maçons que fizeram a história do Brasil. São Paulo: Editora A Gazeta Maçônica, 1973.

CASTELLANI, José. Antonio Bento: um nome esquecido no movimento abolicionista. São Paulo: A Gazeta Maçônica, 1981.

CASTELLANI, José. Os maçons e abolição da escravidão. $2^{\circ}$ Edição. Porto Alegre, Rio Grande do Sul: A Trolha, 2000.

CASTELLANI, José. Piratininga: história da loja maçônica tradição de São Paulo. Edição comemorativa do ano do Sesquicentenário. São Paulo: OESP, 2000.

CASTELLANI, José; CARVALHO, Willian Almeida. História do Grande Oriente do Brasil: a maçonaria na história do Brasil. São Paulo: Madras, 2009.

DAIBERT, Robert Júnior. Isabel, a redentora dos escravos: uma história da princesa entre olhares negros e brancos (1846-1988). Bauru, São Paulo: EDUSC, 2004. 
EVOY, Carmem Mc. El regreso del héroe: Bernardo $\mathrm{O}^{\prime}$ Higgins y su contribución em La construcción del imaginário nacional chileno, 1868-1869. In: EVOY, Carmem Mc. Funerales Republicanos em América del Sur: Tradición, ritual y nación (1832-1896). Santiago: Ediciones Centro de Estudios Bicentenario, 2006.

FERREIRA, Ligia Fonseca. Luiz Gama (1830-1882) étude sur la vie et I' oeuvre d'um noir citoyen, poete et militant de La cause antiesclavagiste au Brésil. Paris: Université Paris III, Sorbonne, 2001.

FERREIRA, Ligia Fonseca. Com a palavra, Luiz Gama: poemas, artigos, cartas, máximas. São Paulo: Imprensa Oficial do Estado de São Paulo, 2011.

FRANCISCO, Flávio Thales Ribeiro. Fronteiras em definição: identidades negras e imagens dos Estados Unidos e da África no jornal O Clarim da Alvorada (1924-1932). São Paulo: Alameda, 2013.

GOMES, Flávio. Negros e política (1888-1937). São Paulo: Zahar, 2005.

GRAINHA, Manuel Borges. História da Franco-maçonaria em Portugal (1733-1912). $6^{\circ}$ Edição. Tradução: Antônio Carlos de Carvalho. Coleção Janus. Lisboa: Veja, 2011.

HOBSBAWM, Eric; RANGER, Terence. (Org). A invenção das tradições. Tradução Celina Cardim Cavalcanti. São Paulo: Paz e Terra, 2012.

MACHADO, Maria Helena Pereira Toledo. O plano e o pânico: os movimentos sociais na década da abolição. São Paulo: UFRJ/Edusp, 1994.

MICELI, Paulo. O mito do herói nacional. (Coleção repensando a história). $4^{\circ}$ Edição. São Paulo: Contexto, 1994. 
MOREL, Marco. As transformações dos espaços públicos: imprensa, atores políticos e sociabilidades na cidade Imperial (1820-1840). São Paulo: Hucitec, 2005.

MOREL, Marco; SOUZA, Françoise Jean de O. O poder da Maçonaria: a história de uma sociedade secreta no Brasil. Rio de Janeiro: Nova Fronteira, 2008.

OLIVEIRA, Cecília Helena de Salles. Musei Paulista: um espaço celebrativo e memória da Independência. In: BRESCIANI, Stella; NAXARA, Márcia (Org). Memória e (res) sentimento: indagações sobre uma questão sensível. $2^{a}$ Edição. São Paulo, Campinas: Editora Unicamp, 2011. p.195-219.

OLIVEIRA, Maria Luiza Ferreira. Entre a casa e o armazém: relações sociais e experiência da urbanização em São Paulo, 1850-1900. São Paulo: Alameda, 2005.

OTSUKA, Alexandre Ferro. Antonio Bento: discurso e prática abolicionista em São Paulo da década de 1880. (Dissertação de Mestrado). Universidade de São Paulo, Programa de Pós-graduação História Social. São Paulo, 2015.

PINTO, Ana Flávia Magalhães. Imprensa negra no Brasil do século XIX. São Paulo: Selo Negro, 2010.

PINTO, Ana Flávia Magalhães. Fortes laços em linhas rotas: literatos negros, racismo e cidadania na segunda metade do século XIX. (Tese de Doutorado). Universidade Estadual de Campinas, 2014.

QUINTÃO, Antonia Aparecida. Irmandades negras: outro espaço de luta e resistência (São Paulo: 1870-1890). São Paulo: Annablume, 2002. 
REIS, Andressa M. B. Zumbi: historiografia e imagens. (Dissertação de Mestrado). Universidade Estadual Paulista, UNESP, Faculdade de História, Direito e Serviço. Franca, 2004.

RIBEIRO, Luaê Carregari Carneiro. Uma América em São Paulo: a Maçonaria e o Partido Republicano. (Dissertação de Mestrado). Universidade de São Paulo, São Paulo, Faculdade de Filosofia, Letras e Ciências Humanas, 2011.

RIOS, Flávia Matheus. Elite política negra no Brasil: relação entre movimento social, partidos políticos e Estado. (Tese de Doutorado). Universidade de São Paulo, São Paulo, Faculdade de Filosofia, Letras e Ciências Humanas, 2014.

SIEGEL, Micol. Mães pretas, filhos cidadãos. In: CUNHA, Olívia Maria Gomes da; GOMES, Flávio dos Santos (Org.). Quase-cidadão: histórias e antropologias da pósemancipação no Brasil. Rio de Janeiro: Editora Faculdade de Getúlio Vargas, 2007. p. 315-347. 
NOTA SOBRE A AUTORA

\section{Renata Ribeiro Francisco}

renataribeirofrancisco@gmail.com

Universidade de São Paulo

São Paulo

São Paulo

Brasil

\section{ENDEREÇO DE CORRESPONDÊNCIA}

Renata Ribeiro Francisco

Universidade de São Paulo

Faculdade de Filosofia, Letras e Ciências Humanas

Departamento de História

Avenida Professor Lineu Prestes, 338

05508-000

São Paulo - SP - Brasil

\section{FINANCIAMENTO}

O presente artigo é desdobramento da pesquisa de doutorado, financiada pelo CNPq.

\section{CONFLITO DE INTERESSE}

Nenhum conflito de interesse declarado.

Copyright

História da

Historiografia:

International Journal

of Theory and History

of Historiography.

Este é um artigo

distribuído em Acesso

Aberto sob os termos

da Licença Creative

Commons Atribuição-

Nã o Com ercial-

SemDerivações 4.0

International. 